EMPOWER : Jurnal Pengembangan Masyarakat Islam

Vol. 5, No.1, Juni 2020, hlm. 155-173

e-ISSN : 2580-0973, p-ISSN : 2580-085X

Tersedia Online di : http://syekhnurjati.ac.id/jurnal/index.php/empower

Email : empowerjurnal@gmail.com

\title{
Perjuangan Orang Mapnan Mempertahankan Hutan di Kabupaten Berau: Kritik Terhadap Antroposentrisme dalam Pengelolaan SDA
}

\author{
Ismar Hamid* \\ (Program Studi Sosiologi, Fakultas Ilmu Sosial dan Ilmu Politik, Universitas \\ Lambung Mangkurat) \\ Email: ismar.hamid@ulm.ac.id,
}

\begin{abstract}
Anggi Yus Susilowati**
(Program Studi Pengembangan Masyarakat Islam, Fakultas Ushuluddin Adab Dakwah, IAIN Syekh Nurjati Cirebon)

Email: anggiyuss@gmail.com
\end{abstract}

Article History

Submitted: 26.04.2020; Revised: 22.06.2020; Accepted: 22.06.2020;

\begin{abstract}
Environmental crisis that more worsening is a consequence of dominance of anthropocentrism that views the existence of nature only to meet human needs, so that its utilization is oriented to commodity production and ignores its sustainability. Tropical forests, which have a vital function in stabilizing the Earth's climate are also being targeted for exploitation. This research aims to describe and analyze the forms of Orang Mapnan's struggle in maintaining the sustainability of tropical forests in Long Ayap Village, Berau Regency, East Kalimantan. This study employed a qualitative approach with a case study. The results show that Orang Mapnan's consciousness increased based on the fact that deforestation has continue to increase. The forms of struggle carried out are maintaining the production type of hunting and gathering even though faced with the influence of indicators of progress and happiness that generated by anthropocentrism; reorganize the cultivation system so that clearing of primary forest for the concerns of community cultivation can be stopped; resist forest conversion for new palm oil plantations; establish a collective vision that promotes environmental sustainability; promote
\end{abstract}


a model of forest utilization by sustainable manner for economic purposes through coffee agroforestry program, which was established to be a utilization model that is permitted in APL forests in Long Ayap Village. Thus the struggle carried out began by resist the growth of the anthropocentric character within themselves, and then stemming the entry of external elements to carry out destructive utlilization of forests. The struggle carried out so far has been quite successful, although in the future it is predicted to face more complex challenges.

Keywords: Anthropocentrism, Forest Sustainibility, Orang Mapnan.

\begin{abstract}
Abstrak
Krisis lingkungan yang semakin memburuk merupakan konsekuensi dari dominasi anthroposentrisme yang memandang keberadaan alam hanya untuk memenuhi kebutuhan manusia, sehingga pengelolaannya diorientasikan untuk produksi komoditas dan mengabaikan keberlanjutannya. Hutan tropis, yang memiliki fungsi vital dalam menstabilkan iklim bumi-pun menjadi sasaran eksploitasi. Penelitian ini bertujuan untuk mendeskripsikan dan menganalisa bentukbentuk perjuangan Orang Mapnan dalam mempertahankan keberlanjutan hutan tropis di Kampung Long Ayap, Kab. Berau, Kalimantan Timur. Penelitian ini menggunakan metode kualitatif dengan pendekatan studi kasus. Hasil penelitian menunjukkan bahwa kesadaran Orang Mapnan terus berkembang berdasar pada fakta deforestasi yang terus meningkat. Bentuk-bentuk perjuangan yang dilakukan adalah mempertahankan corak kehidupan berburu dan meramu meskipun dihadapkan dengan pengaruh indikator-indikator kemajuan dan kebahagiaan produk anthroposentrisme; menata ulang sistem perladangan agar pembukaan hutan perawan untuk kepentingan perladangan masyarakat dapat dihentikan; menolak konversi hutan untuk perkebunan sawit baru; menetapkan visi kolektif yang mengusung keberlanjutan lingkungan hidup; mempromosikan model pengelolaan hutan secara lestari untuk tujuan ekonomi melalui program agroforestry kopi, yang kemudian ditetapkan menjadi model pengelolaan yang dibolehkan pada hutan APL di Kampung Long Ayap. Dengan demikian perjuangan yang dilakukan dimulai dari meredam berkembangnya watak anthroposentris
\end{abstract}


dalam diri mereka, dan kemudian membendung masuknya elemen-elemen luar melakukan pengelolaan hutan yang destruktif. Perjuangan yang dilakukan sejauh ini cukup berhasil, meski ke depan diprediksi akan menghadapi tantangan yang lebih kompleks.

Kata Kunci: Anthroposentrisme, Keberlanjutan Hutan, Orang Mapnan.

\section{PENDAHULUAN}

Filsafat Aristoteles dalam buku Politics menyatakan "tumbuhan disiapkan untuk kepentingan binatang dan binatang disediakan untuk kepentingan manusia". Artinya, manusia dan kepentingannya dianggap paling menentukan dalam tatanan ekosistem. Kepentingan tumbuh-tumbuhan dan binatang menempati urutan kedua sebab ia sebatas pelayan kebutuhan manusia ${ }^{1}$. Manusia bukanlah makhluk ekologis yang identitasnya dibentuk oleh alam, namun manusia adalah makhluk sosial dengan norma dan nilai yang terbentuk dari akal budi, yang secara etis tidak belaku pada makhluk lain. Manusia adalah subjek ilmu pengetahuan, sedangkan alam adalah objek $^{2}$. Pemikian demikian menjadi landasan filosofis mind map anthroposentrisme, yang merupakan salah satu etika dalam pengelolaan lingkungan.

Mind map anthroposentris memandang keberadaan alam hanya untuk memenuhi kebutuhan manusia, sehingga kerusakan alam akibat pemanfaatan yang dilakukan oleh manusia adalah hal yang wajar ${ }^{3}$. Chiras dalam Yusuf (2000) menyatakan bahwa watak antroposentris terbangun dari 3 persepsi, yakni memandang: 1) alam dan bumi sebagai sumber kehidupan yang tidak terbatas; 2) manusia sebagai makhluk eksklusif, atau berada di luar alam; 3) alam sebagai sesuatu yang perlu dikuasai, hanya

1 Rachmad K. Dwi Susilo, Sosiologi Lingkungan \& Sumber Daya Alam (Jakarta: Rajawali Pers, 2012), p. 61.

2 A. Sonny Keraf, Etika Lingkungan (Yogyakarta: Kanisius, 2010), p. 8.

${ }^{3}$ Marion Glaser, 'The Social Dimension in Ecosystem Management: Strengths and Weakness of Human-Nature Mind Maps', Human Ecology Review, 13.2 (2006), 12242 (p. 126). 
yang menguntungkan manusia yang perlu dilindungi dan dimanfaatkan, sementara yang tidak menguntungkan ditelantarkan saja ${ }^{4}$.

Terdapat 5 watak manusia yang tidak bisa dipisahkan dari Anthroposentrisme, yakni: 1) The cornuopia view of nature, yakni pandangan yang beranggapan bahwa alam terbentang luas dan tak akan pernah habis, sehingga setiap orang dapat leluasa memanfaatkannya; 2) Faith in technology, yakni keyakinan bahwa manusia dapat secara optimal memanfaatkan alam dengan teknologi, dan perkembangan teknologi diyakini akan mampu mengatasi berbagai kerusakan alam yang muncul; 3) Growth ethic, yakni etika ingin terus maju, tidak puas dengan segala yang dimiliki, sehingga perusahaan-perusahaan ditantang untuk memproduksi barang-barang baru dengan konsekuensi SDA semakin banyak dieksploitasi; 4) Materialism, yakni paham yang menjadikan kepemilikan benda dan harta sebagai tolak ukur keberhasilan; 5) Individualism, yakni sikap dan keyakinan yang menekankan dorongan personal tanpa memikirkan kepentingan dan kerugian di pihak lain ${ }^{5}$.

Pengelolaan lingkungan akhirnya diorientasikan untuk pemenuhan kebutuhan manusia. Masalah besar muncul ketika sistem ekonomi pasar mengambil alih kontrol atas pengelolaan SDA. Dalam ekonomi pasar, prinsip pemanfaatan terhadap SDA adalah memaksimalkan keuntungan dan akumulasi kapital. Ideologi pembangunan sebagian besar didasarkan pada gagasan pemanfaatan seluruh SDA untuk produksi komoditas ${ }^{6}$. Dengan demikian keberlanjutan lingkungan menjadi aspek yang terabaikan.

Hutan tropis, yang memiliki fungsi vital dalam menstabilkan iklim bumi berdasar pada fungsinya sebagai penyerap karbon dan penghasil oksigen yang sangat besar karena kondisinya yang terus hijau sepanjang tahun, pun menjadi sasaran eksploitasi untuk produksi bahan baku berbagai komoditi pasar. Di Kalimantan Timur, tidak sedikit hutan tropis

\footnotetext{
${ }^{4}$ Susilo, p. 62.

5 Sunyoto Usman, Pembangunan Dan Pemberdayaan Masyarakat (Yogyakarta: Pustaka Pelajar, 2012), p. 288.

6 Vandana Shiva and Maria Mies, Ecofeminism: Perspektif Gerakan Perempuan Dan Lingkungan (Yogyakarta: IRE Press, 2005), p. 81.
} 
yang telah dikonversi menjadi lahan perkebunan sawit dan areal pertambangan. Selain itu, aktifitas logging perusahaan pemilik HPH yang telah berlangsung selama puluhan tahun turut berkontribusi atas berkurangnya tutupan hutan yang signifikan.

WWF melaporkan bahwa Kalimantan telah kehilangan $45 \%$ hutannya hingga tahun 2015. Jika laju penebangan hutan tidak berubah, Kalimantan diyakini akan kehilangan 6 juta Ha hutan hingga tahun 2020, atau tersisa kurang dari sepertiga dari luas hutan sebelumnya ${ }^{7}$. Situasi yang berdampak pada terjadinya perubahan iklim yang semakin memburuk, bahkan tidak berlebihan jika dikatakan bahwa bumi sedang menghadapi krisis iklim jika melihat fakta-fakta yang terjadi hari ini. Eksploitasi alam yang berlangsung terus menerus menyebabkan hilangnya fungsi-fungsi ekosistem tertentu yang berimplikasi pada terjadinya instabilitas ekosistem bumi, atau krisis lingkungan.

Menghadapi kondisi tersebut sebagian besar orang lebih berharap pada perkembangan sains dan teknologi untuk menghadirkan solusi, daripada membatasi pola konsumsi dan pola produksi mereka sendiri. Belum sepenuhnya disadari bahwa standar kehidupan material yang tinggi mengambil kualitas hidup yang sesungguhnya terutama jika persoalan kerusakan ekologi dipahami dengan baik ${ }^{8}$. Menurut Naes, krisis lingkungan dewasa ini hanya bisa diatasi dengan melakukan perubahan cara pandang dan tindakan manusia terhadap alam secara fundamental dan radikal. Artinya, dibutuhkan etika lingkungan hidup yang menuntun manusia untuk berinteraksi dengan cara baru dalam alam semesta. Mengubah kesalahan fundamental-filosofis dalam pemahaman cara pandang manusia mengenai dirinya, alam dan tempat manusia dalam keseluruhan ekosistem?.

Di Kabupaten Berau Kalimantan Timur, terdapat satu kelompok masyarakat yang masih bertahan dengan corak kehidupan yang harmonis

\footnotetext{
7 WWF, 'Kalimantan Bakal Kehilangan 75 Persen Hutan Pada 2020', 6 Juni 2017 $<$ https://www.dw.com/id/wwf-kalimantan-bakal-kehilangan-75-persen-hutanpada-2020/a-39124270>.

8 Vandana Shiva and Mies, p. 66.

${ }^{9}$ Keraf, pp. $2-3$.
} 
dengan alam (hutan). Mereka menyebut diri Orang Mapnan. Meski demikian, mereka dihadapkan dengan berbagai aktifitas pengelolaan SDA yang berwatak Anthroposentris. Penelitian ini fokus pada Orang Mapnan yang mendiami Kampung Long Ayap. Tujuannya adalah mendeskripsikan dan menganalisa bentuk-bentuk perjuangan dalam menghadapi berbagai kegiatan yang telah dan berpotensi menyebabkan deforestasi, serta capaian dan tantangannya ke depan. Harapannya, perjuangan Orang Mapnan mempertahankan keberlanjutan hutan semakin maju, terorganisir dengan baik dan mendapatkan dukungan secara luas.

Penelitian ini menggunakan metode kualitatif dengan pendekatan studi kasus. Lokasi penelitian berada di Kampung Long Ayap, Kecamatan Segah, Kab. Berau, Kalimantan Timur. Informan dalam penelitian adalah perwakilan dari seluruh keluarga, unsur pemerintahan kampung, lembaga adat, karang taruna, PKK dan tokoh agama di Kampung Long Ayap. Seluruh informan tersebut berkedudukan sebagai informan kunci (key informant). Data dikumpulkan dengan menggunakan teknik observasi, wawancara dan dokumentasi, serta diperkuat dengan data sekunder dari studi pustaka. Adapun analisis data menggunakan model Miles and Huberman yang terdiri dari reduksi data, penyajian data dan penarikan kesimpulan ${ }^{10}$.

\section{HASIL DAN PEMBAHASAN}

Kampung Long Ayap; Penyanggah Kehidupan yang Sedang Terancam

Secara administratif, Kampung (Desa) Long Ayap terletak di Kec. Segah, Kab. Berau, Kalimantan Timur, tepatnya di bagian hulu salah satu sungai terbesar di Kab. Berau yakni Sungai Segah. Kampung Long Ayap dihuni oleh $57 \mathrm{KK}$, dengan populasi 199 orang yang terdiri dari 90 perempuan dan 109 laki-laki ${ }^{11}$. Wilayah Kampung Long Ayap berada pada ketinggian 300 - $800 \mathrm{MDpl}$, dengan luas keseluruhan 34.095 Ha yang merupakan hamparan hutan hujan tropis dengan keanekaragaman hayati di dalamnya. Wilayah tersebut saat ini telah diklasifikasi, yang terdiri dari

\footnotetext{
10 Sugiyono, Metode Penelitian Dan Pengembangan (Bandung: Alfabeta, 2015), p. 246.

11 Data RPJMK Long Ayap, p. 10.
} 
13.605 Ha Hutan Lindung (HL), 12.433 Ha Hutan Produksi Terbatas (HPT) dan 8.057 Ha Areal Penggunaan Lain (APL) ${ }^{12}$.

Meski terdapat klasifikasi status lahan, namun masyarakat Long Ayap masih bertahan pada pandangan bahwa seluruh wilayah kampung mereka adalah kawasan hutan. Tidak mengherankan sebab beberapa tahun yang lalu seluruh wilayah yang saat ini termasuk dalam wilayah administrasi Kampung Long Ayap masih berbentuk hutan perawan dengan vegetasi yang sangat rapat. Hutan-hutan tersebut dipergunakan oleh masyarakat untuk areal berburu. Bahkan kegiatan berburu masyarakat menembus seluruh wilayah di bagian hulu Sungai Segah yang masih berbentuk hutan belantara tanpa dibatasi oleh batas-batas administratif kampung.

Dengan luas dan kerapatan vegetasinya, tidak sedikit karbon yang mampu diserap dari atmosfer oleh hutan tropis yang terdapat di wilayah hulu Sungai Segah tersebut. Maka kedudukannya tidak berlebihan jika dianggap sebagai penyangga kehidupan atau penjaga iklim bumi. Namun penetapan wilayah administratif kampung yang dibarengi dengan pengklasifikasian status lahan menghadirkan ancaman terhadap keberlanjutan hutan yang sejak dulu dijaga dan menjadi tempat hidup masyarakat.

Pengklasifikasian tersebut pada akhirnya menjadi alat legitimasi masuknya perusahaan mengeksploitasi hutan untuk kepentingan produksi komoditi pasar, yang dimulai dengan masuknya perusahaan pemilik izin Hak Pengusahaan Hutan (HPH). Di Long Ayap, saat ini terdapat 3 perusahaan HPH yang beroperasi di atas Hutan Produksi Terbatas, yakni PT. Inhutani Segah Hulu dengan luas $1.127 \mathrm{Ha}$, PT. Inhutani Labanan dengan luas 4.061 Ha dan PT. Sumalindo Unit IV dengan luas $7.245 \mathrm{Ha}^{13}$. Meski perusahaan-perusahaan tersebut diwajibkan untuk menerapkan sistem tanam satu tebang satu sebagai komitmen membendung laju deforestasi, namun aktifitasnya tidak bisa menghindari degradasi tutupan hutan yang berimplikasi pada menurunnya fungsi penyerapan karbon.

\footnotetext{
${ }^{12}$ Data RPJMK Long Ayap, p. 8.

${ }^{13}$ Data RPJMK Long Ayap, p. 9.
} 
Selanjutnya, perusahaan perkebunan sawit pun masuk dan mengkonversi hutan yang termasuk dalam APL. Saat ini, terdapat 2 perusahaan yang telah beroperasi, yakni PT. Mulia Inti Persada dengan luas $1.750 \mathrm{Ha}$ dan PT. Sanggam Harapan Sejahtera dengan luas $2.117 \mathrm{Ha}^{14}$. Berarti, secara nyata 3.867 Ha hutan tropis di Long Ayap telah dikonversi menjadi perkebunan sawit. Tentunya, keberlanjutan hutan di Long Ayap terus menghadapi ancaman, bukan hanya hutan pada Areal Penggunaan Lain yang tersisa dan Hutan Produksi Terbatas, bahkan areal Hutan Lindung pun menghadapi ancaman di masa yang akan datang.

\section{Corak Kehidupan Berburu dan Meramu: Pertanda Keseimbangan Alam}

Orang luar menganggap bahwa masyarakat Long Ayap termasuk dalam rumpun Dayak Punan, lebih tepatnya Punan Segah. Dalam kajian etnografi, naman Punan digunakan untuk setiap kelompok masyarakat yang berada di pedalaman Kalimantan, yang hidup hanya dari berburu binatang dan mengumpulkan buah-buahan serta tanaman yang dapat dimakan, serta hidupnya berpindah-pindah di dalam hutan rimba yang lebat ${ }^{15}$. Masyarakat Long Ayap sendiri menyebut diri mereka Orang Mapnan, daripada menggunakan nama Punan. Sampai saat ini tidak ada hasil kajian lebih jauh yang menjelaskan tentang relasi antara masyarakat Long Ayap dengan Orang Punan di belahan Kalimantan lainnya. Orang Mapnan mendiami beberapa kampung/desa di Kab. Berau, khususnya di Hulu Sungai Segah dan Sungai Kelay.

Bagi Orang Mapnan, hutan adalah segala-galanya. Hutan bukan hanya belantara yang berisi pepohonan, namun hutan adalah sumber kehidupan. Selain produksi padi dengan cara berladang, praktis kehidupan mereka masih bergantung pada apa yang disediakan alam (hutan dan sungai). Lebih tepatnya, mereka masih bertahan dengan corak kehidupan berburu dan meramu. Berburu, artinya memenuhi kebutuhan hidup dengan mencarinya di hutan dan sungai, baik makanan maupun sumber ekonomi lain seperti emas, gaharu, madu, rotan dan lain-lain. Sedangkan, Meramu

\footnotetext{
14 Data RPJMK Long Ayap, p. 9.

15 Dkk Koentjaraningrat, Masyarakat Terasing Di Indonesia (Jakarta: PT. Gramedia, 1993), p. 100.
} 
artinya mereka masih bergantung pada apa yang disediakan alam. Mereka belum menerapkan sistem perencanaan pengelolaan sasaran produksi untuk memproduksi sesuatu yang mereka inginkan. Sebagai contoh, praktek bertani yang dipraktekkan di desa-desa yang lebih modern, dimana masyarakatnya telah memiliki perencanaan pengolahan lahan sesuai dengan komoditi yang diinginkan, atau yang disebut dengan intensifikasi pertanian. Bahkan telah dilakukan rekayasa dengan adanya berbagai teknologi seperti sistem irigasi yang memungkinkan produksi tetap berjalan meskipun di musim kemarau.

Sederhananya masyarakat Long Ayap masih sangat bergantung pada musim. Misalnya, pada musim kemarau mereka berburu emas sebab debet air sungai berkurang sehingga memungkinkan untuk mencari emas; pada musim buah mereka akan mencari buah dan sekaligus berburu hewan sebab hewan-hewan buruan akan mudah ditemukan pada musim itu; dan, pada musim hujan mereka berladang. Terdapat pula temuan tertentu yang menentukan aktifitas masyarakat, misalnya adanya temuan gaharu oleh anggota masyarakat tertentu, maka kegiatan berburu gaharu pun dimulai.

Kesimpulannya, alam mampu menyediakan segala yang dibutuhkan masyarakat, seperti makanan, obat-obatan dan sumber-sumber penghasilan lainnya. Hal tersebut menentukan corak kehidupan dan relasi masyarakat Long Ayap dengan alam. Willian Chang (2001) menjelaskan bahwa pada masa keseimbangan alam manusia hanya memanfaatkan sumber daya yang disediakan alam. Manusia masih hidup berburu dan meramu. Pengetahuan-pengetahuan lokal sangat menghormati "eksistensi" makhluk hidup dan tak hidup. Sehingga keseimbangan antar unsur-unsur ekosistem terjaga dengan baik ${ }^{16}$.

Dengan demikian, corak kehidupan masyarakat Long Ayap bukanlah penanda keterbelakangan, namun penanda bahwa keseimbangan alam masih terjaga dan mereka ingin menjaga keberlanjutannya. Hal tersebut diperkuat dengan fakta bahwa masyarakat Long Ayap bukanlah masyarakat yang tidak mengetahui perkembangan zaman. Mereka sangat terbuka terhadap arus informasi, termasuk tentang kehidupan modern.

16 Susilo, p. 54. 
Namun mereka bertahan dengan corak kehidupan berburu dan meramu yang didorong oleh pengalaman dan keyakinan bahwa lingkungan yang berkualitas akan menghadirkan kehidupan yang berkualitas pula. "Tempat nongkrong yang paling nikmat adalah di hutan"17. Hal tersebut merupakan bentuk nyata perlawanan terhadap watak anthroposentrisme yang bisa tumbuh dalam diri mereka, dengan menolak indikator-indikator kemajuan dan kebahagiaan produk anthroposentrisme.

\section{Penataan Ulang Sistem Berladang: Untuk Menghentikan Pembukaan Hutan Perawan}

Kegiatan berladang masyarakat Long Ayap adalah kegiatan menanam padi untuk memenuhi kebutuhan subsisten. Mereka berladang sekali setahun untuk memenuhi kebutuhan sepanjang tahun, bahkan hasilnya terkadang cukup untuk memenuhi kebutuhan dalam 2 - 3 tahun. Kegiatan berladang (tanam padi) tersebut mulai dilakukan pada awal tahun 1970an. Rata-rata luasan ladang mereka adalah 0,5 - $1 \mathrm{Ha} / \mathrm{KK}$, tergantung jumlah anggota keluarga. Berarti areal hutan yang dimanfaatkan untuk berladang setiap tahunnya paling banyak hanya $57 \mathrm{Ha}$, untuk perhitungan 57 KK penduduk Long Ayap saat ini.

Orang Mapnan menerapkan sistem berladang pindah-pindah. Artinya, setiap kali berladang mereka menempati lokasi yang berbeda dari lokasi sebelumnya. Sistem tersebut merupakan implementasi pengetahuan bahwa tanah akan mengalami penurunaan kesuburan setiap kali telah digunakan berladang. Semakin sering ditanami tanah tersebut akan semakin kehilangan kesuburannya. Sehingga perlu direhabilitasi untuk mengembalikan kesuburannya dengan membiarkannya menjadi hutan kembali. Pengetahuan tersebut sejalan dengan penjelasan Lahajir (2001), yang mengatakan bahwa sistem perladangan berpindah adalah pola adaptasi yang sangat penting guna memulihkan lahan setelah ditanami padi, dan secara umum dianggap sebagai satu-satunya sistem pertanian yang sesuai dengan ekosistem hutan tropis ${ }^{18}$.

\footnotetext{
17 Kutipan Pernyataan Saming (Ketua Karang Taruna Long Ayap), Wawancara yang Dilakukan Pada Tanggal 27 Februari 2019.

${ }^{18}$ HE. Benyamine, Pengetahuan Lokal (Banjarbaru: Scripta Cendekia, 2018), p. 68.
} 
Pada masa lalu, Orang Mapnan berladang pindah-pindah secara bebas, atau membuka hutan untuk berladang tanpa terikat oleh aturan tertentu. Sehingga lokasi berladang tidak menentu. Penetapan lokasi berladang hanya didasarkan pada pertimbangan tertentu, seperti tingkat keamanan dari hewan-hewan yang mematikan dan/atau pertimbangan lainnya. Hal ini pernah terjadi di masa lampau, ketika mereka menetapkan lokasi berladang yang didasarkan pada tujuan untuk menghindari banyaknya lintah yang membahayakan kehidupan. Penetapan lokasi berladang juga dibarengi dengan perpindahan pemukiman. Keputusan tersebut diambil setelah beberapa anak meninggal karena lintah. Selain itu, lokasi berladang didekatkan dengan sumber-sumber makanan lain, seperti buah, ikan, hewan buruan, dan bahkan tempat mencari gaharu, emas, madu, rotan dan lain-lain. Hal tersebut untuk memudahkan mereka mengontrol ladangnya sambil berburu.

Desa adalah entitas sadar dan aktif dalam memproduksi pengetahuan sekaligus mengaplikasikan pengetahuan tersebut bagi kapasitas pemecahan masalah, pemenuhan kebutuhan dan proses merespon dinamika perubahan ${ }^{19}$. Masyarakat Long Ayap membuktikan teori tersebut. Sadar bahwa terjadi penurunan kualitas lingkungan sekitar karena adanya deforestasi. Serta adanya stimulus pengetahuan maupun peraturan yang dinilai objektif, misalnya tentang larangan mengelola bantaran sungai. Maka mereka mulai menerapkan sistem penetapan areal untuk lokasi berladang, yang berbeda dengan sebelumnya dimana mereka bebas menetapkan lokasi berladang.

"Sekarang kita tidak boleh lagi membuka hutan baru, kita harus jalankan kesepakatan. Kita berladang di bekas-bekas ladang kita yang di darat saja"20. Dalam hal ini, mereka tetap berladang berpindah-pindah namun arealnya terkonsentrasi dalam satu hamparan, yakni di sepanjang pinggiran jalan masuk kampung. Lokasi tersebut telah mereka jadikan tempat berladang dalam 3 tahun terakhir. Di atas lokasi tersebut setiap KK dapat menjalankan

\footnotetext{
19 Darmawan Salman, Sosiologi Desa: Revolusi Senyap Dan Tarian Kompleksitas (Makassar: Ininnawa, 2012), p. 133.

${ }^{20}$ Kutipan Pernyataan Nyuh Mang (Ketua Adat Long Ayap), yang Disampaikan Pada Musyawarah Setelah Pesta Panen Tahun 2019.
} 
siklus 7 lahan. Artinya, dapat dilakukan perpindahan ladang 7 kali dalam satu periode, atau kembali pada titik pertama setelah 7 tahun, dimana lahan tersebut telah berubah menjadi hutan belantara. Bahkan dalam kurun 1 tahun saja lahan tersebut telah berubah jadi hutan, yang menandakan tingkat kesuburan tanahnya masih sangat normal.

Jika dikalkulasi maka setiap KK memiliki areal perladangan dengan luas antara 3,5 - 7 Ha. Berarti areal perladangan untuk seluruh masyarakat Long Ayap adalah 199,5 - 399 Ha. Dimana setiap tahun mereka hanya menggunakan 28,5 - $57 \mathrm{Ha}$, sementara yang lain berbentuk atau kembali menjadi hutan, begitulah siklusnya secara terus menerus. Adapun kata Darat artinya lokasinya jauh dari sungai, yakni lebih dari $1 \mathrm{Km}$ dari Sungai Segah. Sementara bekas-bekas ladang yang berada di bantaran sungai telah direhabilitasi dengan menanam kayu-kayuan, seperti gaharu, buah-buahan, ulin dan lain-lain, dimana sebagian telah berubah menjadi hutan belantara.

Sistem tersebut secara langsung mampu meredam laju deforestasi dari kegiatan berladang. Serta dibarengi dengan kegiatan rehabilitasi yang mampu mengembalikan tutupan hutan pada bekas-bekas ladang di bantaran Sungai Segah. Praktek maju yang dilakukan masyarakat Long Ayap merupakan bentuk penolakan terhadap watak anthroposentrisme yang memandang bahwa alam semesta terbentang luas dan tidak akan pernah habis, sehingga bisa dieksploitasi untuk menghasilkan segala yang diinginkan manusia. Sebaliknya masyarakat Long Ayap menjunjung tinggi arti penting keserasian antara manusia dengan lingkungan hidupnya, tidak ada yang boleh tereksploitasi.

\section{Menolak Konversi Hutan untuk Pembukaan Lahan Perkebunan Sawit: Pertentangan Pemikiran Ekosentrisme vs Anthroposentrisme}

Telah diurai pada bagian (2) di atas bahwa di Kampung Long Ayap saat ini telah eksis perusahaan perkebunan sawit dan perusahaan logging. Untuk perkebunan sawit, saat ini telah beroperasi 2 perusahaan. Adapun 1 perusahaan lagi sedang berusaha untuk masuk, yakni PT. Agrindo dengan luas areal yang disasar adalah 3.295 Ha. Areal tersebut berada di Areal Penggunaan Lain (APL) yang sebagian besar masih berbentuk hutan 
perawan. Masyarakat menolak masuknya perusahaan tersebut, dengan alasan pokok tidak ingin adanya pembukaan hutan lagi.

Di sisi lain, perusahaan tetap berusaha untuk masuk dengan memanfaatkan mekanisme perizinan dari pemerintah. Namun hingga saat ini perusahaan belum memiliki izin HGU. Dalam hal ini, secara nyata terjadi konflik antara masyarakat dengan perusahaan. Sejak awal Januari tahun 2019, pihak Pemkab. Berau bersama Tim Mediator yang dibentuk telah melakukan upaya mediasi. Namun hingga saat ini belum ada hasil dari mediasi tersebut. Masyarakat tegas menolak dengan alasan tidak ingin hutan di Long Ayap terus terdegaradasi.

Penolakan tersebut terbangun dari kesadaran dalam melihat perubahan kondisi hutan di Long Ayap. Kondisi terkini sangat kontras dengan kondisi 10 tahun yang lalu, dimana hampir seluruh wilayah Kampung Long Ayap masih berbentuk tutupan hutan. Hanya pemukiman masyarakat dengan luasan sekitar $5 \mathrm{Ha}$ dan areal perladangan dengan luasan keseluruhan hanya 20-30 Ha, yang tutupan hutannya terbuka. Sehingga, dari sekitar 34.095 Ha luas wilayah Kampung Long Ayap, paling banyak hanya $35 \mathrm{Ha}$ yang terbuka tutupan hutannya. Luas areal perladangan tersebut teramat kecil jika dibandingkan luas wilayah operasi perusahaan HPH dan perusahaan perkebunan sawit yang telah eksis saat ini.

Dari sudut pandang sosiologi lingkungan, di Kampung Long Ayap terjadi pertentangan etik pengelolaan lingkungan. Masyarakat Long Ayap yang hidup harmonis dengan alam bertentangan dengan elemen luar yang ingin mengelola SDA untuk memproduksi komoditi pasar. Pertentangan tersebut merupakan bentuk pertentangan pemikiran yang cenderung ekosentris yang diwakili oleh masyarakat dengan pemikiran anthroposentris yang diwakili oleh perusahaan. Ekosentrisme memandang bahwa manusia hanya menjadi satu subsistem alam semesta, atau sistem sosial dianggap sebagai bagian dari sistem alam dan atau kebutuhan sosial sebagai subordinat pada syarat-syarat ekosistem. Etika lingkungan yang diperjuangkan dan dibela oleh ekosentrisme adalah masyarakat yang menjunjung tinggi local wisdom sebagai syarat mutlak pengelolaan 
lingkungan yang sustainable ${ }^{21}$. Paham ekosentrisme muncul sebagai tanggapan atas pandangan-pandangan filsafat Anthroposentrisme yang terbukti tidak bijak mengatur hubungan manusia dengan alam ${ }^{22}$.

Bisa dikatakan pula bahwa pertentangan tersebut merupakan bentuk pertentangan watak dan kesadaran yang terbentuk pada ruang dan waktu yang berbeda. Watak dan kesadaran masyarakat Long Ayap terbentuk pada ruang dan waktu dimana keseimbangan alam masih terjaga. Sedangkan elemen luar adalah masyarakat yang watak dan kesadarannya terbentuk pada masa dimana alam tidak lagi seimbang dan percaya bahwa peralatan modern, teknologi dan organisasi sosial yang mutakhir, mampu melakukan rekayasa alam. Lingkungan fisik (tanah, topografi, cuaca dan sumber-sumber mineral) maupun lingkungan biologis (hewan dan tumbuh-tumbuhan) bisa diberdayakan untuk kepentingan manusia (determinan teknologi) ${ }^{23}$.

Sehingga, perlawanan masyarakat bukanlah bentuk penolakan terhadap kemajuan. Namun kesadaran bahwa alam yang seimbang mampu memenuhi kebutuhan manusia, tidak perlu bergantung pada rekayasa alam. "Sejak dulu apa saja yang kita butuhkan kita cari di hutan... Tidak berlebihan juga, tapi kebutuhan kita terpenuhi... Turun temurun Orang Mapnan memang menjaga hutan, karena kita hidup dari situ... Kita tidak mau hutan kita berkurang lagi, cukup yang di seberang (sungai) saja yang lepas"24. Secara historis, Orang Mapnan adalah suku pengembara (penjelajah) hutan. Bagi Orang Mappnan hutan adalah segala-galanya. Hutan bukan hanya belantara yang berisi pepohonan, namun merupakan sumber kehidupan. Sehingga, keserasian antara manusia dengan hutan harus dijaga, tidak ada yang boleh tereksploitasi.

Nilai tersebut berlaku secara turun temurun dan diperjuangkan bahkan ketika saat ini diperhadapkan dengan berbagai tawaran menggiurkan dari pihak perusahaan, seperti pengadaan kebun plasma,

\footnotetext{
${ }^{21}$ Glaser, p. 123.

22 Susilo, p. 105.

23 Susilo, p. 57.

${ }^{24}$ Kutipan Pernyataan Katben (Kepala Kampung/Desa Long Ayap). Wawancara Pada Tanggal 10 Februari 2019
} 
penyerapan tenaga kerja lokal, bantuan pembangunan kampung dan lainlain. Dalam hal ini, nilai yang diperjuangkan Orang Mapnan tidak terbentuk secara mekanik, namun terbentuk secara organik atas dasar kesadaran yang dominan terbangun berdasarkan pengalaman (perjalanan) hidup. Sebagaimana yang dikatakan Marx bahwa "Social existence determines social consciousness" (keberadaan sosial seseorang menentukan kesadaran sosialnya $)^{25}$.

\section{Agroforestry Kopi: Model Pengelolaan Hutan yang Berkelanjutan}

Fakta menunjukkan bahwa dari 8.057 Ha APL di Kampung Long Ayap, 3.867 Ha telah dikonversi menjadi lahan perkebunan sawit. Sehingga dari keseluruhan wilayah APL tersebut tersisa kurang dari 4.000 Ha yang masih berbentuk tutupan hutan. Dimana 3.295 Ha diantaranya saat ini sedang diincar oleh satu perusahaan baru untuk dikonversi lagi menjadi lahan perkebunan sawit. Terjadinya deforestasi yang cukup massif dalam beberapa tahun terakhir melahirkan kekhawatiran akan kerusakan alam yang semakin besar. Kekhawatiran tersebut membentuk kesadaran baru pada masyarakat Long Ayap untuk melakukan berbagai upaya dalam membendung laju pembukaan hutan.

Masyarakat Long Ayap menyadari bahwa diperlukan bentuk perjuangan yang lebih strategis untuk mempertahankan keberlanjutan hutan. Upaya strategis dimulai dengan menetapkan visi kolektif yang prokeberlanjutan lingkungan, yakni "Terwujudnya Kampung Long Ayap yang Berdaulat Atas Sumber-sumber Kehidupan, Menjunjung Tinggi Nilai Budaya dan Lestari Untuk Masa Depan Generasi Penerus"26. Salah satu tantangan besar dalam upaya pencapaian visi tersebut adalah pentingnya memunculkan model pengelolaan hutan untuk tujuan ekonomi yang mengusung prinsip berkelanjutan (lestari). Dalam hal ini, sasaran pengelolaan yang dimaksud adalah hutan yang termasuk dalam APL. Sebab masyarakat menyadari bahwa diperlukan model pengelolaan yang menjadi antitesa model pengelolaan destruktif yang mensyaratkan pembukaan tutupan hutan.

\footnotetext{
${ }^{25}$ Nur Sayyid Kristeva, Negara Marxis Dan Revolusi Proletariat (Yogyakarta: Pustaka Pelajar, 2011), pp. 201-2.

${ }^{26}$ Data RPJMK Long Ayap, p. 24.
} 
Agroforestry kemudian menjadi model pengelolaan yang didorong oleh masyarakat.

Agroforestry adalah sistem tata guna lahan yang sesuai dengan praktek-praktek budaya dan kondisi lingkungan setempat, yang secara sederhana dipahami sebagai sistem pengolahan lahan yang mengkombinasikan pohon dan tanaman pertanian ${ }^{27}$. Pada prakteknya masyarakat Long Ayap memilih tanaman kopi varietas Liberika sebagai tanaman prioritas. Kopi tersebut secara ilmiah tidak memerlukan pembukaan tutupan hutan dalam membudidayakannya, atau secara langsung mampu mempertahankan tutupan hutan dan bahkan menambah jumlah tegakan pohon.

Selain itu, kopi bukanlah jenis tanaman yang asing bagi masyarakat Long Ayap. Sejak dulu mereka telah menanam kopi meskipun bukan dengan model pertanian intensif. Dari segi ekonomi, kopi adalah jenis komoditi unggulan karena merupakan kebutuhan pokok masyarakat. Selain itu, komoditi kopi untuk skala lokal Kabupaten Berau dan Kalimantan Timur masih tergolong sangat langka. Sehingga, pemasaran hasil produksinya kelak tidak akan menemui kendala.

Dalam perjalanannya, program agroforestry kopi ini terealisasi setelah masyarakat Long Ayap menjalin kerjasama dengan NGO Payopayo, yang di Kab. Berau bergerak pada isu konservasi hutan melalui skema pemberdayaan masyarakat. Sehingga program yang diusung masyarakat relevan dengan program yang sedang dikerjakan NGO Payopayo. Hingga saat ini terestimasi 155 Ha hutan dalam APL telah ditanami kopi varietas Liberika. Penanaman dilakukan dengan tanpa melakukan penebangan pohon sama sekali, hanya memanfaatkan space antar pohon dalam areal hutan tersebut.

Kegiatan penanaman dilakukan secara kolektif yang dimotori oleh perempuan, sementara laki-laki tetap melakukan aktifitas berburu. Adapun untuk pengelolaannya disepakati skema kolektif, yang bertujuan untuk menghindari privatisasi lahan. Sehingga lahan budidaya tersebut menjadi

27 Johan Iskandar, Manusia, Budaya, Dan Lingkungan: Kajian Ekologi Budaya (Bandung: Humaniora Utama Press, 2001), p. 4. 
aset bersama masyarakat, dimana hanya hak kelola yang dimiliki oleh individu masyarakat yang diatur oleh pemerintah kampung. Dengan demikian, hingga saat ini 155 Ha hutan pada APL Kampung Long Ayap telah terselamatkan dari model pengelolaan yang distruktif. Pemerintah dan masyarakat Long Ayap memprogramkan untuk terus memperluas wilayah agroforestry, bahkan menargetkan seluruh wilayah APL yang belum dikonversi jadi lahan perkebunan sawit akan ditanami kopi. Program ini mengusung spirit "Emhui Tna = Emhui Lasngan Blom"28, artinya "Menjaga Hutan= Menjaga Nafas Kehidupan".

Tentunya, model pengelolaan tersebut adalah bentuk pengelolaan hutan yang berkelanjutan (lestari) untuk tujuan ekonomi. Hutan terhindar dari model pengelolaan yang destruktif dan masyarakat pun tetap mendapatkan sumber-sumber ekonomi di luar dari pendapatan langsung, seperti hewan buruan, emas, gaharu, rotan, madu dan lain-lain. Dengan demikian, terjadi hubungan timbal balik yang harmonis antara manusia dengan alam. Hal tersebut sejalan dengan konsep ekologi manusia Terry Rambo, yang menyatakan bahwa hubungan timbal balik antara sistem sosial dan ekosistem melalui pertukaran energi, materi dan informasi dapat berjalan dengan baik dan teratur karena adanya arus input dan output yang seimbang ${ }^{29}$.

\section{SIMPULAN}

Kesadaran masyarakat Long Ayap terus berkembang dalam upaya mempertahankan keberlanjutan hutan, yang didorong fakta deforestasi yang terus meningkat dalam beberapa tahun terakhir. Bentuk-bentuk perjuangan yang dilakukan adalah: Pertama, mempertahankan corak kehidupan berburu dan meramu meskipun dihadapkan dengan pengaruh indikator-indikator kemajuan dan kebahagiaan produk anthroposentrisme; Kedua, menata ulang sistem perladangan agar pembukaan hutan perawan untuk kepentingan perladangan masyarakat dapat dihentikan; Ketiga,

\footnotetext{
${ }_{28}$ Kutipan Pernyataan Saming (Ketua Karang Taruna Long Ayap), Wawancara Pada Tanggal 15 Februari 2019.

29 A. Terry Rambo, Conceptual Approaches to Human Ecology (Hawaii: East-West Environment and Policy Institute Honolulu, 1983), p. 25.
} 
menolak konversi hutan untuk perkebunan sawit baru; Keempat, menetapkan visi kolektif yang mengusung keberlanjutan lingkungan; Kelima, mempromosikan model pengelolaan hutan secara lestari untuk tujuan ekonomi melalui program agroforestry kopi, yang kemudian ditetapkan menjadi model pengelolaan yang dibolehkan pada hutan APL di Kampung Long Ayap.

Masyarakat Long Ayap tegas menolak nilai dominasi manusia atas alam yang merupakan watak konstruksi anthroposentrisme. Etika yang diperjuangkan adalah terpeliharanya relasi yang harmonis dan seimbang antara manusia dan hutan, tidak ada yang tereksploitasi. Dengan demikian perjuangan yang dilakukan Orang Mapnan dimulai dari meredam berkembangnya watak Anthroposentris dalam diri mereka, dan kemudian membendung masuknya elemen-elemen luar melakukan pengelolaan hutan yang destruktif. Perjuangan yang dilakukan sejauh ini cukup berhasil, meski ke depan diprediksi akan menghadapi tantangan yang semakin kompleks. Tentunya, dukungan berbagai pihak pro-keberlanjutan lingkungan sangatlah dibutuhkan. Yang terpenting jangan pandang mereka terbelakang, hormati kebudayaannya, dan biarkan mereka menjaga nafas kehidupan untuk kita semua. 


\section{DAFTAR PUSTAKA}

Benyamine, HE., Pengetahuan Lokal (Banjarbaru: Scripta Cendekia, 2018)

Data RPJMK Long Ayap

Glaser, Marion, 'The Social Dimension in Ecosystem Management:

Strengths and Weakness of Human-Nature Mind Maps', Human Ecology Review, 13.2 (2006), 122-42

Iskandar, Johan, Manusia, Budaya, Dan Lingkungan: Kajian Ekologi Budaya (Bandung: Humaniora Utama Press, 2001)

Keraf, A. Sonny, Etika Lingkungan (Yogyakarta: Kanisius, 2010)

Koentjaraningrat, Dkk, Masyarakat Terasing Di Indonesia (Jakarta: PT. Gramedia, 1993)

Kristeva, Nur Sayyid, Negara Marxis Dan Revolusi Proletariat (Yogyakarta: Pustaka Pelajar, 2011)

Rambo, A. Terry, Conceptual Approaches to Human Ecology (Hawaii: EastWest Environment and Policy Institute Honolulu, 1983)

Salman, Darmawan, Sosiologi Desa: Revolusi Senyap Dan Tarian Kompleksitas (Makassar: Ininnawa, 2012)

Sugiyono, Metode Penelitian Dan Pengembangan (Bandung: Alfabeta, 2015)

Susilo, Rachmad K. Dwi, Sosiologi Lingkungan \& Sumber Daya Alam (Jakarta: Rajawali Pers, 2012)

Usman, Sunyoto, Pembangunan Dan Pemberdayaan Masyarakat (Yogyakarta: Pustaka Pelajar, 2012)

Vandana Shiva, and Maria Mies, Ecofeminism: Perspektif Gerakan Perempuan Dan Lingkungan (Yogyakarta: IRE Press, 2005)

WWF, 'Kalimantan Bakal Kehilangan 75 Persen Hutan Pada 2020', 6 Juni

$2017<$ https://www.dw.com/id/wwf-kalimantan-bakal-kehilangan-75persen-hutan-pada-2020/a-39124270>

Wawancara dengan Ketua Adat Long Ayap, yang Disampaikan Pada Musyawarah Setelah Pesta Panen Tahun 2019

Wawancara dengan Kepala Kampung/Desa Long Ayap, pada tanggal 10 Februari 2019

Wawancara dengan Ketua Karang Taruna Long Ayap, pada tanggal 15

Februari 2019 